\title{
What are the impacts of small-scale dredging activities on inland fisheries productivity? A systematic review protocol
}

\author{
Belinda M. S. Ward-Campbell ${ }^{1^{*}}$ (D) and Brent Valere ${ }^{2}$
}

\begin{abstract}
Background: Small-scale dredging activities in freshwater bodies have the potential to impact habitats and food resources that fishes depend on, and ultimately impact fisheries productivity. This systematic review will explore the evidence base for small-scale dredging impacts on the indicators of fisheries productivity, and will help to inform management decisions that seek to reconcile biodiversity conservation and freshwater fisheries, with potentially disruptive anthropogenic activities in freshwater environments.

Methods: This systematic review will examine, summarize and synthesize all available evidence on the impacts of small-scale dredging activities on surrogate indicators of fisheries productivity. All studies in freshwater habitats in temperate regions in both the Northern and Southern hemispheres will be considered. Both peer reviewed primary and grey literature will be included in the review, and searches will be conducted in academic journal databases, online search engines, and specialist websites. Study validity will be critically assessed to identify any risk of bias. Data will be presented as a narrative synthesis, and if sufficient good quality data are available, a meta-analysis will be performed.
\end{abstract}

Keywords: Evidence-based policy, Fisheries management, Fish habitat, Fish abundance, Fish biomass, Freshwater

\section{Background}

Freshwater ecosystems are essential to life, and are thus critical for the development and maintenance of human societies. Globally, freshwater is a limited resource, comprising only a fraction $(<0.01 \%)$ of the volume of the world's surface water, and covering only $0.8 \%$ of the Earth [1]. Freshwater ecosystems are rich in biodiversity, and support approximately $12 \%$ of the world's known species, which includes roughly a third of the world's vertebrate taxa [1]. Human activities as well depend on the services provided by healthy freshwater ecosystems: fresh water, waste treatment, transportation, flood control, tourism, recreation, cultural benefits, and food resources in the form of fisheries [2-5].

Freshwater fisheries are globally important ecosystem services [6] providing commerce, recreation, and a

\footnotetext{
*Correspondence: belinda.wardcampbell@gmail.com

177 Gildner Street, Kitchener, ON, Canada

Full list of author information is available at the end of the article
}

low-cost dietary protein source to millions of people $[6$, 7]. These fisheries are particularly important in developing nations, where subsistence fishing provides an essential source of nutrition for millions of impoverished people [8]. Conversely, inland fisheries in developed nations tend more toward recreational and commercial fisheries, each presenting their own management challenges $[9,10]$. Fish species of value to subsistence, commercial or recreational fisheries cannot exist in isolation, but rather are part of a complex ecosystem of interconnected habitats and species. Habitat quantity and quality are essential for fish productivity [11], and there is a positive relationship between biodiversity, healthy ecosystems and the provisioning of services [12-14].

Yet, freshwater ecosystems are among the most globally imperilled, and threats to freshwater habitat and biodiversity have been thoroughly documented [e.g. 15-17].

Among the primary threats to freshwater ecosystems and the fish populations they support is the degradation and destruction of habitat through anthropogenic 
activities $[15,18,19]$. Biodiversity conservation is frequently at odds with other ecosystem services required and anthropogenic uses of freshwater, leading to conflicting management priorities. Effective management requires the identification and reconciliation of trade-offs between biodiversity or fisheries productivity and human uses in freshwater systems [20,21], to provide transparent, defensible evidence-based decisions. To this end, the rigorous methodology employed by systematic reviews and related meta-analyses make them a valuable tool in making informed fisheries management decisions [22].

\section{Review topic identification and stakeholder input}

Recent changes to the Canadian Fisheries Act switched the focus of promoting sustainable fisheries in Canada from an approach of managing the habitats sustaining fish populations, to one that manages the ongoing productivity of fishes related to commercial, recreational, or aboriginal (CRA) fisheries [23]. For the purpose of this review, we will follow the definition of fisheries productivity laid out it Randall et al. [24] as "the sustained yield of all component populations and species and their habitat which support and contribute to a fishery". Very few projects require assessment at the scale of an entire fishery [24], so assessments of smaller projects focus on surrogates for effects on productivity [25]. The Fisheries Protection Program has established a number of conceptual pathways of effects (PoE) for development projects with the potential to affect fisheries productivity. These PoE describe development projects in terms of the cause and effects relationships known to exist, and the mechanisms through which the stressors lead to effects. Each cause and effect relationship is represented by a line, termed a pathway, leading from the activity to the potential stressor and then to the ultimate effect on fish and fish habitat. For example, dredging may result in a change in aquatic macrophytes (vegetation) and this may ultimately affect fish populations through a change in food resources (Fig. 1). It should be noted that pathways are highly generalized, and in the assessment of projects, the impacts and predicted changes in fisheries productivity need to be carefully and expertly considered prior to the project start [25].

In order to streamline the assessment of projects, the Fisheries Protection Program of Fisheries and Oceans Canada is implementing tools to aid in the self-assessment of smaller projects, as well as adapting existing resources for the decision-making process involving larger projects [23]. Accordingly, the review of the impacts of small-scale dredging activities on inland fisheries productivity has been explicitly proposed by the Canadian stakeholder, the Fisheries Protection Program of Fisheries and Oceans Canada (DFO).

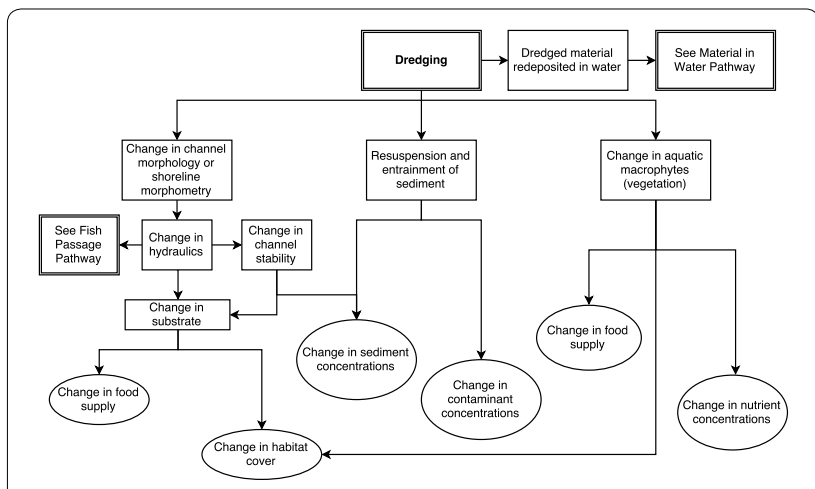

Fig. 1 Pathway of effects for dredging developed by Fishers and Oceans Canada as too to illustrate the potential effects of dredging on fish and fish habitat

This review will use the conceptual framework of the PoE for dredging activities to establish suitable surrogates of fisheries productivity. Dredging activities are common in freshwater environments, and occur in all types of waterbodies; sediments and aquatic vegetation are dredged, both for capital works in lakes and large rivers (e.g. the creation of new harbours), as routine fluvial maintenance (e.g. maintenance of shipping channel depth), or pollution control and remediation of contaminated sediments [19, 26-28].

However, of interest within this review are the dredging activities that may fall within the scope of self-assessment or the assessment of smaller-scale projects that fall under the jurisdiction of the Fisheries Protection Program (e.g. dredging for dock building, pleasure boat access to deep water, agricultural drain maintenance, maintenance of boating channels, etc.), but that may result in broader cumulative effects. Major, large-scale construction projects on industrialized or urban waterfronts, extensive dredging for commercial shipping, or projects involving pollution control or remediation fall outside of this current review.

An advisory team was made up during the formulation of the initial question, and is comprised of topic experts and staff from Fisheries and Oceans Canada. The advisory team guided the focus of the review, and was also consulted on the creation of search terms, development of screening inclusion criteria, and the list of specialist websites.

\section{Objective of the review}

The objective of this systematic review is to assemble and evaluate all available literature on the impacts of small-scale dredging on fisheries productivity in temperate freshwater environments. The review will focus on studies from north-eastern North America and 
north-western Europe, however studies outside those geographic regions but falling within the selected Köppen-Geiger climate regions will also be included. Information collated in this review will be used to answer the primary question.

\section{Primary question}

How does small-scale dredging, both macrophyte and/ or substrate removal, impact correlates of fisheries productivity?

\section{Components of the primary question \\ Subject}

Lentic and lotic freshwater environments in temperate regions-including, but not limited to: lakes, rivers, streams, ponds, canals, wetlands, harbours, ports, and ditches.

\section{Intervention}

Dredging and mechanical excavation/removal of macrophytes and/or sediment.

\section{Comparator}

No intervention.

\section{Outcome}

Changes in correlates of fish productivity-abundance/ species richness of fishes, abundance/density/species richness of benthic invertebrates, available fish habitat (depth, water quality, flow, cover, substrate) encompassing spawning locations, nursery habitat, refuges, and feeding locations.

\section{Methods}

\section{Searches}

\section{Search terms}

Relevant search terms were compiled under three components making up the primary question: subject, intervention, and outcome. Search terms between component categories will be combined using the Boolean operators "AND", and within categories using the operators "AND" and "OR". The proximity operator "NEAR" will be used to combine search terms expected to be in relatively close proximity to one another, but may on their own be too broad. Wildcards will be used to expand the search terms. The asterisk $\left(^{*}\right)$ represents any number of characters (e.g. fish* returns results including fishery, fisheries, fishes, fishing, fished). The dollar sign (\$), in databases where applicable, is a wildcard used to represent zero or one character, and can be used inside or at the end of a word (e.g. harbo $\$$ r returns searches for harbour and harbor). Search order precedence for operators is "NEAR" followed by "AND" and "OR". Parentheses will be used to override the operator precedence, with the expression within parentheses being handled first. The proposed search string appears as:

(stream\$ OR river\$ OR ditch* OR lake* OR reservoir\$ OR pond\$ OR canal\$ OR channel\$ OR wetland\$ OR marsh* OR shore* OR harbo\$r* OR port)

\section{AND}

(dredg* OR excavat* OR dig OR (remov* NEAR/5 (macrophyte\$ OR sediment\$ OR vegetation)))

\section{AND}

((fish* OR habitat\$ OR macroinvertebrat* OR invertebrat* OR macrofauna\$) AND (abundan* OR biomass OR

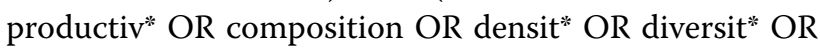
disturb* OR impact* OR change* OR effect\$))

\section{Abbreviated search}

Where a complex search string is not accepted, search terms will be modified with the aid of the database help menu, and will follow the format of the simplified phrase: (dredg* OR excavat*) AND (impact*) AND (fish* OR habitat). All modified search strings will be recorded.

\section{Language}

Only English search terms will be used to conduct all searches. All references returned will be included in the database, including any articles written in other languages, however, they will not be translated and used in the review itself.

Estimating search comprehensiveness In order to estimate the comprehensiveness of our search strings, we will test the search against a predetermined "test set" of approximately 10 relevant articles. We will also search the bibliographies of the test set articles to ensure that any relevant articles cited are also present in our search results. If any articles are found to be missing from our search, our search string will be amended. The test set of articles is created by obtaining articles from the advisory team, and searching the personal publications of lead investigators in the field for highly relevant articles.

\section{Publication databases}

1. ISI Web of Science Core Collection

2. WAVES (Fisheries and Oceans Canada)/Federal Science Library)

3. Science.gov

4. ProQuest Dissertations and Theses

5. ProQuest Environmental Sciences and Pollution Management

\section{Search engines}

The first 100 hits (based on relevance) will be examined for inclusion in the review. For citation purposes, as well 
as for repeatability and transparency, dates of access of online material from search engine searches will be recorded.

\section{Google Scholar}

7. Google

\section{Specialist websites}

The first 50 documents returned from each search will be included in the reference database and be examined for relevance and inclusion in the review. Bibliographies of included material will be searched for any relevant documents to be included in the reference database. Links appearing in relevant documents will be followed to any organisation not originally included in the specialist website search, in order to encompass all available literature. All documents will initially be exported into Mendeley prior to assessment.

8. Centre for Environment, Fisheries and Aquaculture Science

9. Central Dredging Association

10. Commonwealth Scientific and Industrial Research Organization (Australia)

11. Department for the Environment, Food and Rural Affairs (UK)

12. Environment Agency (UK)

13. European Dredging Association

14. European Environment Agency

15. Fisheries and Oceans Canada

16. Food and Agriculture Organization of the United Nations

17. Great Lakes Fisheries Commission

18. International Association for Great Lakes Research

19. International Association of Dredging Companies

20. Joint Nature Conservation Committee

21. National Institute of Water and Atmospheric Research (NZ)

22. National Park Service

23. Natural England

24. Nature Conservancy

25. REFORM (http://wiki.reformrivers.eu/index.php/ Main_Page)

26. Salmon and Trout Conservation UK

27. Trout Unlimited

28. United Nations Environment Programme

29. US Fish and Wildlife Service

30. US Forest Service

31. World Wide Fund for Nature

\section{Other literature searches}

The reference sections of all articles retained for full article reviewing, as well as any review papers, will be searched by hand for any titles missed in the search strategy, including symposium titles and unpublished literature. These titles will also be included in the database, with reference made to the originating article. Web-based bibliographies will also be checked for missed sources. Both manual searches will check the comprehensiveness of the search strategy. Authors of unpublished literature or unobtainable articles will be contacted to request access to the full article, or when no article is available, access to the data.

\section{Search record database}

Publications retrieved from each of the searches (publication databases, search engines, and specialist websites) will be put into separate Mendeley databases. On completion of the initial searches they will be compiled into CADIMA (systematic review software http://www. cadima.info). Duplicates will be identified and merged.

\section{Article screening and study inclusion criteria}

Articles will be screened in two stages; screening will take place at the title and abstract, and full text stage. Prior to any screening occurring, two reviewers will check for screening consistency and the repeatability of screening decisions using the greater of either $10 \%$ of the articles, or 100 articles. Cohen's kappa coefficient will be calculated to determine the level of agreement between the 2 reviewers. A kappa score of $\geq 0.6$ indicates substantial agreement, and must be achieved before further article review. Discrepancies will be discussed, and if required, the inclusion criteria will be reviewed. Similar consistency checks will take place at all three levels of article screening.

All article screening decisions will be recorded in the database, with justification for all inclusion/exclusion decisions. When there is not enough justification for exclusion, the article will pass to the next stage in the screening process. If the abstract is absent, the article will pass directly to the full-text screening stage. Any article excluded at the full-text stage of the screening process will be included, with reasons for exclusion, with the final review as an appendix.

\section{Inclusion criteria}

Relevant subject(s) Temperate freshwater systems, including both lentic and lotic environments. Freshwater bodies can include, but are not limited to, lakes, rivers, streams, reservoirs, ponds, canals, channels, harbours, marches, ports, ditches, and wetlands. To determine if a study falls within the temperate zone, we will use the Köppen-Geiger climate classification [29], and restrict studies to temperate oceanic climate, hot-summer humid continental climate, and warm-summer humid continen- 
tal climate zones in both the northern and southern hemispheres.

Relevant types of intervention Dredging activities to remove either sediment, or vegetation (or both), for purposes including, but not limited to, small dock construction of a size suitable to accommodate pleasure boats, or increasing depth (for recreational boating traffic or canal/ agricultural drain maintenance). Dredging activities not included in this review include dredging for pollution control or remediation, large-scale dredging in major rivers and lakes (e.g. St. Lawrence River) for commercial shipping traffic, dredging projects for mining, or channelization projects.

Relevant types of comparator A control site that is either a site consisting of similar physical habitat features, but not undergoing intervention, within the same water body, or a similar site on an adjacent water body. Before intervention data of the same site.

Relevant types of outcome A measurable effect (change/ no change) in abundance/density/species richness of fish, abundance/density/species richness of benthic macroinvertebrates, habitat features (e.g. depth, vegetation, cover, flow, substrate composition, structure, bank/shore composition).

Relevant types of study design Study designs considered for inclusion in the review include: studies that compare relevant outcomes before and after intervention (Before/ After-BA), studies that compare relevant outcomes between a control site and a site subject to intervention (Control/Impact-CI), studies designed to include both spatial and temporal comparators (Before/After/Control/ Impact-BACI). Review papers and policy discussions will be searched for relevant references, but will otherwise not be included in this review.

\section{Potential effect modifiers and reasons for heterogeneity}

The following factors may cause variation in measured outcomes, and information on these potential effect modifiers will be extracted and recorded in the MS-Excel spreadsheet when available. Additional effect modifiers may be added during the course of the review. The list of effect modifiers was compiled in consultation with the advisory team.

- Study location (coordinates)

- Waterbody (lentic/lotic-lake/river/stream)

- Methodology of dredge (e.g. barge/excavator, land based excavator, etc.)

- Duration of dredge
- Extent of dredging

- Time/season of dredging

- Time since last dredge (if dredging was for routine maintenance)

- Pre/post monitoring effort

- Length of monitoring

- Frequency of monitoring

- Fish species data-life history information including spawning times

- Taxonomic level of invertebrates

- Habitat structure

- Biotic habitat components

- Abiotic habitat components

- Sample size

\section{Study validity assessment}

Studies passing the full-text screening stage of the review will be subject to critical appraisal in order to assess the internal and external validity of the study. Articles will be appraised on the a number of selected parameters, which include, but are not limited to, the following:

- Study design (BA/CI/BACI)

- Location

- Temporal extent of study-short-term/long-term

- Replication-replicated/unreplicated

- Pre-dredging data-single instance/multiple sampling events

- Potential effect modifiers-identified and/or accounted for

- Objectives/hypotheses-clarity in relation to methodology

- Use of reference/control sites

- Statistical analyses

Adapted from the Cochran Collaboration's 'risk of bias' tool [30], Bilotta et al. [31] have outlined criteria for the assessment of internal validity in environmental science. Criteria include assessing for selection bias, performance bias, attrition bias, reporting bias, as well as biases applicable in unique situations. The criteria outlined in Bilotta will be used to assess each article included in the review. A risk assessment of "low risk", "high risk", or "unclear risk" will be assigned to the information from each article, and will be used to assess the potential risk of bias of the article. All information, as well as the risk assessment will be recorded in the database.

\section{Data extraction strategy}

All data extracted from studies included in the review will be recorded in an MS-Excel spreadsheet. Extracted information will include study characteristics including sample sizes, measured outcome means, measures of 
variation (standard error, standard deviation), comparators. This information will be used to assess the impact of small-scale dredging activities on aspects of fisheries productivity. When data are presented only in tables and graphs, data will be extracted when possible and the information recorded in the spreadsheet. If information is not easily decipherable, the corresponding author of the article will be contacted to request the information. When only raw data are available, summary statistics will be calculated and recorded. If sufficient data of high enough quality are extracted, a meta-analysis may be performed.

To ensure that data are extracted in a way that is both consistent and repeatable, two reviewers will extract information from the same subset of 10 articles. Extracted information will be compared and any inconsistencies will be discussed. All extracted data entered will be made available as a supporting document with the final review.

\section{Data synthesis and presentation}

A narrative synthesis from all studies of sufficient validity included in the review will be generated and will describe the validity of the results, as well as the findings. The synthesis will be presented as visually as possible, with the addition of tables and figures. If sufficient data of similar outcomes is available, meta-analysis may be possible. In such cases, effects sizes will be standardized and weighted appropriately. If data allows, subgroup analysis of different waterbody types (lentic vs lotic) may be possible. Publication bias and sensitivity analysis will be performed when possible. Publication bias will be assessed using the Egger test to produce a funnel plot of the standardised mean difference plotted against the standard error of the standardised mean difference $[32,33]$. This review may also identify and highlight major knowledge gaps in the evidence base.

\section{Authors' contributions}

This manuscript was drafted by BWC. BV provided comments. Both authors read and approved the final manuscript.

\section{Author details}

${ }^{1} 77$ Gildner Street, Kitchener, ON, Canada. ${ }^{2}$ Fisheries Protection Program, Fisheries and Oceans Canada, 867 Lakeshore Road, Burlington, ON, Canada.

\section{Acknowledgements}

The authors wish to thank collaborators who provided valuable insight during the protocol process, including: Trina Rytwinski (Carleton University) and Pat Chow-Fraser (McMaster University).

\section{Competing interests}

The authors declare that they have no competing interests. The authors who have also authored articles considered for review will have no direct involvement regarding decisions of inclusion or critical appraisal of those articles.

Ethics approval and consent to participate Not applicable.
Funding

Support for this study was given by Fisheries and Oceans Canada.

\section{Publisher's Note}

Springer Nature remains neutral with regard to jurisdictional claims in published maps and institutional affiliations.

Received: 26 July 2017 Accepted: 5 January 2018

Published online: 19 March 2018

\section{References}

1. Garcia-Moreno J, Harrison I, Dudgeon D, Clausnitzer V, Darwall W, Farrell T, Savy C, Tockner K, Tubbs N. Sustaining freshwater biodiversity in the Anthropocene. In: Bogardi J, Bhaduri A, Leentvaar J, Marx S, editors. The global water system in the anthropocene: challenges for science and governance. Berlin: Springer International Publishing; 2014. p. 247-70.

2. de Groot R, Brander L, van der Ploeg S, Costanza R, Bernard F, Braat L, Christie M, Crossman N, Ghermandi A, Hein L, Hussain S, Kumar P, McVittie A, Portela R, Rodriguez LC, ten Brink P, van Beukering P. Global estimates of the value of ecosystems and their services in monetary units. Ecosyst Serv. 2012;1:50-61.

3. Dodds WK, Perkin JS, Gerken JE. Human impact on freshwater ecosystem services: a global perspective. Environ Sci Technol. 2013;47:9061-8.

4. Russi D, ten Brink P, Farmer A, Badura T, Coates D, Förster J, Kumar R, Davidson N. The economics of ecosystems and biodiversity for water and wetlands. Gland: IEEP, London and Brussels; Ramsar Secretariat; 2013.

5. Green PA, Vörösmarty CJ, Harrison I, Farrell T, Sáenz L, Fekete BM. Freshwater ecosystem services supporting humans: pivoting from water crisis to water solutions. Glob Environ Chang. 2015;34:108-18.

6. Welcomme RL, Cowx IG, Coates D, Béné C, Funge-Smith S, Halls A, Lorenzen K. Inland capture fisheries. Philos Trans R Soc B. 2010;365:2881-96.

7. McIntyre PB, Liermann CAR, Revenga C. Linking freshwater fishery management to global food security and biodiversity conservation. PNAS. 2016;113:12880-5.

8. Beard TD Jr, Arlinghaus R, Cooke SJ, McIntyre PB, De Silva S, Bartley D, Cowx IG. Ecosystem approach to inland fisheries: research needs and implementation strategies. Biol Lett. 2011;7:481-3.

9. Cowx IG, Arlinghaus R, Cooke SJ. Harmonizing recreational fisheries and conservation objectives for aquatic biodiversity in inland waters. J Fish Biol. 2010;76:2194-215.

10. Cooke SJ, Rice JC, Prior KA, Bloom R, Jensen O, Browne DR, Donaldson LA, Bennett JR, Vermaire JC, Auld G. The Canadian context for evidencebased conservation and environmental management. Environ Evid. 2016. https://doi.org/10.1186/s13750-016-0065-8.

11. Lapointe NWR, Cooke SJ, Imhof JG, Boisclair D, Casselman JM, Curry RA, et al. Principles for ensuring healthy and productive freshwater ecosystems that support sustainable fisheries. Environ Rev. 2014;22:110-34. https://doi.org/10.1139/er-2013-0038.

12. Hooper DU, et al. Effects of biodiversity on ecosystem functioning: a consensus of current knowledge. Ecol Monogr. 2005;75:3-35.

13. Balvanera P, Pfisterer AB, Buchmann N, He JS, Nakashizuka T, Raffaelli D, Schmid B. Quantifying the evidence for biodiversity effects on ecosystem functioning and services. Ecol Lett. 2006;9:1146-56. https://doi. org/10.1111/j.1461-0248.2006.00963.x.

14. Pasari JR, Levi T, Zavaleta ES, Tilman D. Several scales of biodiversity affect ecosystem multifunctionality. PNAS. 2013;1 10:10219-22.

15. Dudgeon D, Arthington AH, Gessner MO, Kawabata Zl, Knowler DJ, Lévêque Naiman RJ, Prieur-Richard A, Soto D, Stiassny MJ, Sullivan CA. Freshwater biodiversity: importance, threats, status and conservation challenges. Biol Rev. 2006;81:163-82. https://doi.org/10.1017/ S1464793105006950.

16. Strayer DL, Dudgeon D. Freshwater biodiversity conservation: recent progress and future challenges. J N Am Benthol Soc. 2010;29:344-58. https:// doi.org/10.1899/08-171.1

17. Vörösmarty CJ, McIntyre PB, Gessner MO, Dudgeon D, Prusevich A, Green P, Glidden S, Bunn SE, Sullivan CA, Reidy Liermann C, Davies PM. 
Global threats to human water security and river biodiversity. Nature. 2010;467:555-61. https://doi.org/10.1038/nature09440.

18. Richter BD, Braun DP, Mendelson MA, Master LL. Threats to imperiled freshwater fauna. Conserv Biol. 1997;11:1081-93. https://doi. org/10.1046/j.1523-1739.1997.96236.x

19. Rose CA. Economic growth as a threat to fish conservation in Canada. Fisheries. 2005;30:36-8.

20. Daily GC, Polasky S, Goldstein J, Kareiva P, Mooney HA, Pejchar L, Ricketts TH, Salzman J, Shallenberger R. Ecosystem services in decision making: time to deliver. Front Ecol Environ. 2009;7:21-8. https://doi. org/10.1890/080025.

21. Naeem S, Duffy JE, Zavaleta E. The functions of biological diversity in an age of extinction. Science. 2012;336:1401-6.

22. Cooke SJ, Wesch S, Donaldson LA, Wilson ADM, Haddaway NR. A call for evidence-based conservation and management of fisheries and aquatic resources. Fisheries. 2017;42:143-9. https://doi.org/10.1080/03632415.20 17.1276343.

23. Rice J, Bradford MJ, Clarke KD, Koops MA, Randall RG, Wysocki RW. The science framework for implementing the fisheries protection provisions of Canada's Fisheries Act. Fisheries. 2015;40:268-75.

24. Randall RG, Bradford MJ, Clarke KD, Rice JC. A science-based interpretation of ongoing productivity of commercial, recreational or Aboriginal fisheries. DFO Can Sci Advis Sec Res Doc 2012/112. 2013.
25. Bradford MJ, Randall RG, Smokorowski KS, Keatley BE, Clarke KD. A framework for assessing fisheries productivity for the Fisheries Protection Program. DFO Can Sci Advis Sec Res Doc 2013/067. 2013.

26. Bray RN. Environmental aspects of dredging. Leiden: Taylor and Francis/ Balkema; 2008.

27. Freedman JA, Carline RF, Stauffer JR Jr. Gravel dredging alters diversity and structure of riverine fish assemblages. Freshw Biol. 2013;58:261-74.

28. Watson-Leung T, Graham M, Hartman E, Welsh P. Using a modified dredging elutriate testing approach to evaluate potential aquatic impacts associated with dredging a large freshwater industrial harbor. Integr Environ Assess Manag. 2017;13:155-66.

29. Peel MC, Finlayson BL, McMahon TA. Updated world map of the KöppenGeiger climate classification. Hydrol Earth Syst Sci. 2007;11:1633-44.

30. Higgins JP, Altman DG, Gøtzsche PC, Jüni P, Moher D, Oxman AD, Sterne JA. The Cochran Collaboration's tool for assessing risk of bias in randomised trials. Br Med J. 2011;343:d5928.

31. Bilotta GS, Milner AM, Boyd IL. Quality assessment tools for evidence from environmental science. Environ Evid. 2014:3:14.

32. Egger M, Davey Smith G, Schneider M, Minder C. Bias in meta-analysis detected by a simple, graphical test. BMJ. 1997:315:629-34.

33. Palmer AR. Detecting publication bias in meta-analyses: a case study of fluctuating asymmetry and sexual selection. Am Nat. 1999:154:220-33.

\section{Submit your next manuscript to BioMed Central and we will help you at every step:}

- We accept pre-submission inquiries

- Our selector tool helps you to find the most relevant journal

- We provide round the clock customer support

- Convenient online submission

- Thorough peer review

- Inclusion in PubMed and all major indexing services

- Maximum visibility for your research

Submit your manuscript at www.biomedcentral.com/submit 